\title{
Quality of Life and Professional Activity of Working-Age Patients after Stroke
}

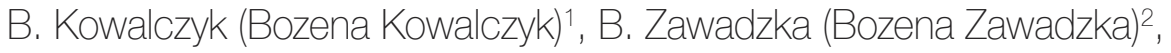 \\ B. Lubinska-Zadlo (Bogumiła Lubinska-Zadlo)'1
}

${ }^{1}$ Faculty of Health Sciences, Podhale State College of Applied Sciences in Original Article Nowy Targ, PL.

${ }^{2}$ Institute of Pedagogy and Psychology, Department of Health Pedagogy, Jan Kochanowski University, PL.

\section{E-mail address:}

kowalczyk.bozena@ppuz.edu.pl

\section{Reprint address:}

Bozena Kowalczyk

Podhale State College of Applied Sciences

Faculty of Health Sciences

ul. Kokoszkow 71

34-400 Nowy Targ

Malopolska

Poland

Source: Clinical Social Work and Health Intervention

Volume: 12

Issue: 4

Pages: $13-22$

Cited references: 26

\section{Reviewers:}

Michael Costello

University of Scranton school of education, USA

Gabriela Lezcano

University of California, San Francisco, USA

\section{Keywords:}

Quality of Life. Stroke. Activity of Working. World Health Organization Quality of Life Questionnaire.

\section{Publisher:}

International Society of Applied Preventive Medicine i-gap

CSWHI 2021; 12(4): 13 - 22; DOI: 10.22359/cswhi_12_4_02 (C Clinical Social Work and Health Intervention

\section{Abstract:}

Background \&objectives: Stroke is one of the most common and severe diseases in terms of the economic burden on society. The aim of this study was to assess the quality of life of people after stroke in the context of professional activity, considering the time since stroke.

Material \& methods: To assess the quality of life, a shortened Polish version of the World Health Organization Quality of Life Questionnaire (WHOQOL-Bref) was used. The study was 
conducted on a group of 279 people with the first stroke diagnosed.

Results: The statistically significant relationship was observed, considering the period after stroke in groups: 6-12 months; 13 months-2 years; $2-5$ years from the onset of stroke. The correlation between professional activity of people after stroke and their quality of life was statistically significant in: the somatic sphere; the social sphere; the environmental sphere.

Conclusions: Undertaking professional activity by people who had a stroke significantly affected the self-assessment of their quality of life and satisfaction with the quality of health, regardless of the period since the onset of the stroke.

\section{Introduction}

It is estimated that until 2030 the number of deaths around the world caused by stroke might be as many as $7.68 \mathrm{mln}$ people and it will be one of more serious medical problems. Regardless of geographical location, stroke is a major cause of permanent disability among adult people often disqualifying them from professional life.

In Poland $1 / 3$ of people who survived stroke die within a year from the moment first symptoms appear. Another 1/3 of people suffer from considerable functional deficits. It mainly shows as hemiparesis, aphasia, dysfunction of higher nervous activity. Those people require permanent care of other people. In the other group of sick people functional impairment is not as serious and they are partially able to exist on their own. This high death-rate in Poland is affected by coexistent diseases, especially cardiovascular diseases (high blood pressure, heart diseases) as well as lung diseases (1). Stroke is one of the most common and most serious diseases considering economic burden of society (2). Oftentimes, it results in people losing their jobs and lower standard of life. Data regarding people returning to work after a stroke differ from $1 \%$ to $91 \%$ depending on a country according to Hartke \& Trierweiler and from $19 \%$ to $73 \%$ according to Treger et al. $(3,4)$. Frequency of stroke is connected to age, more and more often it happens to people in working age. Returning to professional life after a stroke depends on many factors, including: the kind of stroke; neurological deficits; the kind of work that a person did before the stroke (2). Cerebrovascular accident causes permanent neurological damage, which very often makes it impossible for people who suffered from it to come back to the professional life they had beforehand.
Cardiovascular accident causes permanent neurological damage, which makes it impossible for many people to come back to professional life (5). No chance for professional comeback after sick leave caused by stroke involves negative consequences for the sick person - lower quality of life (2). In medical science, there is a definition accepted by WHO which defines the quality of life as: perception of one's social status within such aspects as culture, hierarchy of values, relations to one's objectives, desires, interests, norms designated by environmental conditions (6). The cognitive goal of this paper is analyzzing the correlation between the quality of life of people in working age after stroke and professional activity (working - not working) depending on the time that has passed since the stroke: $1^{\text {st }}$ group 6-12 months; 2nd group 13-24 months; 3rd group 2-5 years since the stroke. At the same time, a connection was searched for: the connection between the quality of life and the time that passed since the stroke.

\section{Material and Methods}

Presented research is only a part of realizing the project of analyzing the quality of life of people of working age after a stroke. The research was done by means of a diagnostic survey. To measure the quality of life a questionnaire with standardized scale by WHOQOL-Bref was used. It was validated to Polish conditions by $\mathrm{L}$. Wołowicka \& K. Jaracz. This questionnaire enables evaluation of the correlation between psychophysical factors such as family relations or professional activity of both a healthy person and a person afflicted with different diseases (7). The questionnaire contains 26 closed questions scored 1-5 points and makes it possible to get 
a profile of life quality in four fields: motor; psychological; social; environmental. The scoring of the fields is positive - the more points the better the quality of life. Initial results were transformed to the scale 0-100 (8).

The obtained results were documented by means of a specially prepared Microsoft Excel program. Statistical evaluation was carried out by means of STATISTICA program. Correlations between the scales were searched for by means of specifying Pearson's rank order coefficients. $\mathrm{P}<0.05$ test probability was accepted as crucial.

The analysis concerned randomly chosen people of working age. The following criteria for choice were taken: age 25-59 for women; 25-64 for men; first stroke diagnosed and defined according to WHO criteria; time after the stroke at least 6 months, but no longer than 5 years; patient's consent to be examined. People who did not meet the criteria were excluded from the examination. 279 persons were examined - all with recognized first stroke. 243 persons suffered from ischemic stroke; 36 persons from hemorrhagic stroke. Those people were treated in $3 \mathrm{Re}-$ habilitation Departments in the south of Poland. Rehabilitation treatment was directed at the aftermath of stroke. People who were examined were divided into 2 groups - 1st group patients who returned to work after the stroke; 2 nd group patients who continued to take social benefits and did not come back to professional life. Next, the examined group was divided into 3 subgroups. The time after the stroke was taken into account. The $1^{\text {st }}$ subgroup were patients 6-12 months after the stroke (103 persons); $2^{\text {nd }}$ subgroup patients 13 months -2 years after the stroke (60 persons); $3^{\text {rd }}$ patients 2 years -5 years after the stroke ( 116 persons). The choice of periods of time was influenced also by basic rehabilitation stages: early hospitalization; functional rehabilitation (up to 12-24 months); time of functional adaptation (up to 5 years) (9). Also, world clinometric recommendations in the field of quality of life and the influence of disease on it were taken into account. They recommend the time for its evaluation after the condition of the patient is stabilized (e.g. after 3,6, 12 months) because earlier results may not be reliable $(6,10)$.

The percentage of people who resumed work after stroke was $17.56 \%$ (49 persons). Before stroke more than half of the examined people
(55.10\%) used to do white-collar jobs, whereas $20.41 \%$ of examined people used to do blue-collar jobs. The average time from the stroke until the examination was $27 \pm 19.63$ months, in the group of people working $28.02 \pm 19.42$ months; in the group of people not working 26.02 \pm 19.69 months. Average age in the examined group was $54.5 \pm 7.52$; in the group of not working people $57.17 \pm 6.76$. The age difference between working and not working people was 5.2 years. In the group of working people, the majority completed secondary education, however in the group of not working people - vocational education. Obtained information shows that the majority of examined people suffered from ischemic stroke (243 persons); hemorrhagic stroke (36 persons); rightsided paresis was diagnosed among 50.18\% (140 persons); left-sided among 49.82\% (139 persons). In the group of working people after stroke left-sided paresis dominated (61.22\%), however, in the group of not working people right-sided paresis dominated $52.61 \%$. The majority of the people examined $(47.67 \%)$ stated that they were in a poor economic situation. The people who resumed professional work after stroke $(38.78 \%)$ stated that their economic situation was good; $52.1 \%$ of not working people declared their economic situation as bad. The majority of examined people (58.78\%) were married; the rest - $20.79 \%$ - are widowers or widows; $13.26 \%$ are single (Table 1).

\section{Results}

Statistically significant correlation between professional activity and self-evaluation of life quality was observed. It depended on the time that passed from the stroke with the exception of people 13-24 months from falling sick. Detailed analysis of the research results by means of WHOQOL-Bref questionnaire showed positive statistically significant correlation with the level of significance $\mathrm{p}=0.001$ in a group of patients: 612 and 25-60 months since the stroke between professional activity and their satisfaction from the quality of life. The obtained result confirms that resuming professional activity is very important for people after stroke because it generates higher appreciation of their life quality in relation to not working people. The result showed the level of appreciation of life quality regarding their professional life in juxtaposition with self- 
Table 1 Sociodemographic parameters of the examined patients $(n=279)$ after stroke in working age.

\begin{tabular}{|c|c|c|c|c|c|c|c|}
\hline \multirow{3}{*}{ Variables } & \multirow{3}{*}{$\begin{array}{l}\text { Category } \\
\text { of answer }\end{array}$} & \multicolumn{6}{|c|}{$\begin{array}{c}\text { Professional } \\
\text { activity }\end{array}$} \\
\hline & & \multicolumn{2}{|c|}{ Working } & \multicolumn{2}{|c|}{ Not working } & \multicolumn{2}{|c|}{ Total } \\
\hline & & $\mathrm{n}$ & $\%$ & $n$ & $\%$ & $n$ & $\%$ \\
\hline \multirow{2}{*}{ Gender } & Woman & 31 & 63.27 & 100 & 43.48 & 131 & 46.95 \\
\hline & Man & 18 & 36.73 & 130 & 56.52 & 148 & 53.05 \\
\hline \multirow{2}{*}{ Age } & Mobile & 9 & 18.37 & 14 & 6.09 & 23 & 8.24 \\
\hline & Not mobile & 40 & 81.63 & 216 & 93.91 & 256 & 91.76 \\
\hline \multirow{4}{*}{ Marital status } & Not married & 7 & 14.29 & 30 & 13.04 & 37 & 13.26 \\
\hline & Married & 31 & 63.27 & 133 & 57.83 & 164 & 58.78 \\
\hline & Divorced & 6 & 12.24 & 14 & 6.09 & 20 & 7.17 \\
\hline & Widower & 5 & 10.20 & 53 & 23.04 & 58 & 20.79 \\
\hline \multirow{4}{*}{ Education } & Primary & 4 & 8.16 & 41 & 17.83 & 45 & 16.13 \\
\hline & Vocational & 14 & 28.57 & 94 & 40.87 & 108 & 38.71 \\
\hline & Secondary & 17 & 34.69 & 66 & 28.70 & 83 & 29.75 \\
\hline & University & 14 & 28.57 & 29 & 12.61 & 43 & 15.41 \\
\hline \multirow{2}{*}{ Paresis side } & Right sided & 19 & 38.78 & 121 & 52.61 & 140 & 50.18 \\
\hline & Left sided & 30 & 61.22 & 109 & 47.39 & 139 & 49.82 \\
\hline \multirow{3}{*}{$\begin{array}{l}\text { Economic } \\
\text { situation }\end{array}$} & Bad & 13 & 26.53 & 120 & 52.17 & 133 & 47.67 \\
\hline & Average & 17 & 34.69 & 74 & 32.17 & 91 & 32.62 \\
\hline & Good & 19 & 38.78 & 36 & 15.65 & 55 & 19.71 \\
\hline \multirow{4}{*}{$\begin{array}{l}\text { Professional } \\
\text { status before } \\
\text { stroke }\end{array}$} & $\begin{array}{l}\text { White } \\
\text { collar worker }\end{array}$ & 27 & 55.10 & 52 & 22.61 & 79 & 28.32 \\
\hline & $\begin{array}{l}\text { Blue } \\
\text { collar worker }\end{array}$ & 10 & 20.41 & 83 & 36.09 & 93 & 33.33 \\
\hline & Farmer & 8 & 16.33 & 26 & 11.30 & 34 & 12.19 \\
\hline & Other & 4 & 8.16 & 69 & 30.00 & 73 & 31.74 \\
\hline
\end{tabular}

assessment of health. The quality of life was higher than satisfaction from health. The results were shown in Table 2.

The analysis of obtained results by means of t-student's test and Pearson's correlation coefficient shows statistically significant correlation between professional work and assessment of satisfaction from one's health in groups of patients no longer than two years since stroke. However, regarding the group longer than 2 years since the stroke such correlation was not seen. Professional activity correlated positively with assessment of satisfaction from health in groups no longer than 2 years from the stroke until the time of examination. The level of correlation significance between variables was $\mathrm{p}=0.000$ in the group 6-12 months and $\mathrm{p}=0.039$ in the group 13 24 months since the stroke. The obtained result suggests that professional activity generates higher self-assessment of one's health, but only in cases no longer than 2 years from the stroke (Table 2).

Analysis of examination result obtained by means of t-Student's test and Spearman's correlation coefficient showed statistically significant correlations between professional activity and quality of life in the somatic sphere in the mentioned time periods to the advantage of working people. The juxtaposition of the correlation between professional activity and quality of life in the somatic sphere in each of the analyzed time periods shows the existence of positive and statistically significant correlations between all the assessed variables. Those results suggest that professional activity generates a higher quality of life in somatic sphere. The level of correlation 
Table $\mathbf{2}$ Correlation between professional activity and assessment of the quality of life and health.

\begin{tabular}{|c|c|c|c|c|c|}
\hline \multirow{5}{*}{$\begin{array}{l}\text { Life } \\
\text { quality } \\
\text { assessment } \\
\text { (Bref1) }\end{array}$} & \multirow{2}{*}{$\begin{array}{l}\text { Time from } \\
\text { the stroke }\end{array}$} & \multicolumn{2}{|c|}{ Professional work } & \multirow{2}{*}{$\begin{array}{c}\text { T-student's } \\
\text { test }\end{array}$} & \multirow{2}{*}{$\begin{array}{l}\text { r-Pearson's } \\
\text { correlation } \\
\text { coefficient }\end{array}$} \\
\hline & & yes & no & & \\
\hline & 6-12 months & 3.75 & 2.95 & $\begin{array}{l}t=-3.446 \\
p=0.001\end{array}$ & $\begin{array}{l}r=0.324 \\
p=0.001\end{array}$ \\
\hline & 13-24 months & 3.44 & 3.16 & $\begin{array}{l}t=-0.803 \\
p=0.425\end{array}$ & $\begin{array}{l}r=0.105 \\
p=0.425\end{array}$ \\
\hline & $25-60$ months & 3.79 & 3.11 & $\begin{array}{l}t=-3.859 \\
p=0.000\end{array}$ & $\begin{array}{l}r=0.295 \\
p=0.001\end{array}$ \\
\hline \multirow{3}{*}{$\begin{array}{l}\text { Health } \\
\text { assessment } \\
\text { (Bref2) }\end{array}$} & 6-12 months & 3.50 & 2.60 & $\begin{array}{l}t=-3.661 \\
p=0.000\end{array}$ & $\begin{array}{l}r=0.342 \\
p=0.000\end{array}$ \\
\hline & 13-24 months & 3.44 & 2.69 & $\begin{array}{l}t=-2.112 \\
p=0.039\end{array}$ & $\begin{array}{l}r=0.267 \\
p=0.039\end{array}$ \\
\hline & $25-60$ months & 3.13 & 2.78 & $\begin{array}{l}t=-1.547 \\
p=0.125\end{array}$ & $\begin{array}{l}r=0.143 \\
p=0.125\end{array}$ \\
\hline
\end{tabular}

between variables in all time periods was $\mathrm{p}=0.000$ (Table 3).

Examining the influence of professional activity on the psychological sphere in each time period it was observed that there were statistically significant correlations in groups of patients 6-12 and 25-60 months after the stroke. The analysis of the correlation between professional activity and psychological sphere in the two above mentioned time periods showed statistically significant positive correlations between variables. The level of correlation significance between variables was $\mathrm{p}=0.000$ in the group 6 $12 ; \mathrm{p}=0.009$ in the group 25-60 months after the stroke. The results show that professional activity affects the level of life quality in the psychological sphere (Table 3).

Analyzing the obtained results the examination of professional activity and the social sphere significant differences were seen as well as correlations between variables in all 3 analyzed time periods since the stroke. The level of correlation significance between variables was respectively: $\mathrm{p}=0.002$ in the group of sick people 6-12 months from the stroke; $\mathrm{p}=0.018$ - in the group 13-24; $\mathrm{p}=0.047-$ in the group 25-60 months from the stroke. Among working people quality of life in social sphere is higher than in the group of people who do not work (Table 3).
The obtained results of Pearson's t-Student's test and Pearson's correlation coefficient show numerous statistically significant differences in different time periods between professional activity and the environmental sphere. The analysis of correlation between variables shows that there are positive and statistically significant correlations in all the examined areas. The level of statistical significance of the correlation between variables was $p=0.000$ in the group of sick people 6-12 months; $\mathrm{p}=0.037$ in the group of sick people $13-24$ months and $p=0.003$ in the group 25-60 months after the stroke. The results prove that working people have a higher quality of life in the environmental sphere than people who do not work (Table 3).

Another area of research was checking to what degree the time that passed since the stroke affects the quality of life of people of working age after stroke among working and not working people. Analyses were done with the use of ANOVA tests - Analysis of Variance and Spearman's correlation coefficients were used. No correlation between the time which passed since the stroke and the feeling of satisfaction from the quality of life and satisfaction from one's health was found. The time which passed since the stroke does not affect the quality of life in the spheres examined by means of WHOQOL-Bref. 
Table 3 Correlation between professional activity and quality of life spheres in the group of examined patients

\begin{tabular}{|c|c|c|c|c|c|}
\hline \multirow{2}{*}{$\begin{array}{l}\text { Quality of } \\
\text { life spheres }\end{array}$} & \multirow{2}{*}{$\begin{array}{l}\text { Time since } \\
\text { the stroke }\end{array}$} & \multicolumn{2}{|c|}{ Professional work } & \multirow{2}{*}{$\begin{array}{c}\text { t-Student's } \\
\text { test }\end{array}$} & \multirow{2}{*}{$\begin{array}{l}\text { r-Pearson'e cor- } \\
\text { relation } \\
\text { coefficient }\end{array}$} \\
\hline & & yes & no & & \\
\hline \multirow{3}{*}{$\begin{array}{l}\text { Somatic } \\
\text { sphere }\end{array}$} & 6-12 months & 62.56 & 40.61 & $\begin{array}{l}t=-5.717 \\
p=0.000\end{array}$ & $\begin{array}{l}r=0.494 \\
p=0.000\end{array}$ \\
\hline & 13-24 months & 64.11 & 41.25 & $\begin{array}{l}t=-4.095 \\
p=0.000\end{array}$ & $\begin{array}{l}r=0.474 \\
p=0.000\end{array}$ \\
\hline & $25-60$ months & 59.92 & 44.43 & $\begin{array}{l}t=-4.763 \\
p=0.000\end{array}$ & $\begin{array}{l}r=0.407 \\
p=0.000\end{array}$ \\
\hline \multirow{3}{*}{$\begin{array}{c}\text { Psychological } \\
\text { sphere }\end{array}$} & 6-12 months & 67.19 & 40.70 & $\begin{array}{l}t=-4.790 \\
p=0.000\end{array}$ & $\begin{array}{l}r=0.430 \\
p=0.000\end{array}$ \\
\hline & 13-24 months & 58.33 & 44.96 & $\begin{array}{l}t=-1.755 \\
p=0.085\end{array}$ & $\begin{array}{l}r=0.225 \\
p=0.085\end{array}$ \\
\hline & $25-60$ months & 57.00 & 45.52 & $\begin{array}{l}t=-2.665 \\
p=0.009\end{array}$ & $\begin{array}{l}r=0.242 \\
p=0.009\end{array}$ \\
\hline \multirow{3}{*}{$\begin{array}{l}\text { Social } \\
\text { sphere }\end{array}$} & 6-12 months & 69.87 & 52.66 & $\begin{array}{l}t=-3.216 \\
p=0.002\end{array}$ & $\begin{array}{l}r=0.305 \\
p=0.002\end{array}$ \\
\hline & 13-24 months & 70.11 & 52.57 & $\begin{array}{l}t=-2.443 \\
p=0.018\end{array}$ & $\begin{array}{l}r=0.305 \\
p=0.018\end{array}$ \\
\hline & $25-60$ months & 64.33 & 55.12 & $\begin{array}{l}t=-2.008 \\
p=0.047\end{array}$ & $\begin{array}{l}r=0.185 \\
p=0.047\end{array}$ \\
\hline \multirow{3}{*}{$\begin{array}{c}\text { Environmental } \\
\text { sphere }\end{array}$} & 6-12 months & 68.13 & 50.23 & $\begin{array}{l}t=-4.402 \\
p=0.000\end{array}$ & $\begin{array}{l}r=0.401 \\
p=0.000\end{array}$ \\
\hline & 13-24 months & 66.78 & 52.96 & $\begin{array}{l}t=-1.132 \\
p=0.037\end{array}$ & $\begin{array}{l}r=0.270 \\
p=0.037\end{array}$ \\
\hline & $25-60$ months & 63.71 & 53.29 & $\begin{array}{l}t=-3.035 \\
p=0.003\end{array}$ & $\begin{array}{l}r=0.273 \\
p=0.003\end{array}$ \\
\hline
\end{tabular}

The quality of life of working people after stroke does not differ significantly from people who do not work (Table 4).

\section{Discussion}

Assessing the quality of life of the people after stroke is not easy because it concerns many spheres of people's lives in a subjective way. Analyzing the quality of life one should take into account not only physical and psychological as- pects but also social and environmental relations (11). Weber-Rajek et al. state that questions about psychological potential of somatic life became important when civilization diseases appeared. Such diseases are defined by psychosocial factors and stroke is one of them (12). The results of this analysis show that professional activity heavily affects quality of life. The somatic sphere was one of the spheres most affected because it makes it possible for more efficient people to start work. 
Table 4 Correlation between the time since the stroke and life involving professional activity considering examined patients' professional activity

\begin{tabular}{|c|c|c|c|c|c|c|c|}
\hline \multirow{2}{*}{$\begin{array}{l}\text { Quality } \\
\text { of life }\end{array}$} & \multirow{2}{*}{$\begin{array}{c}\text { Professional } \\
\text { work }\end{array}$} & \multicolumn{3}{|c|}{ Time since the stroke } & \multirow[t]{2}{*}{ Total } & \multirow[t]{2}{*}{ ANOVA(F) } & \multirow{2}{*}{$\begin{array}{l}\text { Spearman's corre- } \\
\text { lation coefficient }\end{array}$} \\
\hline & & $\begin{array}{c}\text { 6-12 } \\
\text { months }\end{array}$ & $\begin{array}{c}\text { 13-24 } \\
\text { months }\end{array}$ & $\begin{array}{l}25-60 \\
\text { months }\end{array}$ & & & \\
\hline \multirow{2}{*}{$\begin{array}{c}\text { Assess- } \\
\text { ment } \\
\text { of life } \\
\text { quality }\end{array}$} & No & 2.95 & 3.16 & 3.11 & 2.95 & $\begin{array}{c}F(2.227)=0.982 \\
p=0.376\end{array}$ & $\begin{array}{c}\text { Rsp }=0.067 \\
p=0.312\end{array}$ \\
\hline & Yes & 3.75 & 3.44 & 3.79 & 3.75 & $\begin{array}{c}F(2.460)=0.646 \\
p=0.529\end{array}$ & $\begin{array}{c}\text { Rsp }=0.062 \\
p=0.671\end{array}$ \\
\hline \multirow{2}{*}{$\begin{array}{c}\text { Assess- } \\
\text { ment of } \\
\text { health }\end{array}$} & No & 2.60 & 2.69 & 2.78 & 2.69 & $\begin{array}{c}F(2.227)=0.853 \\
p=0.427\end{array}$ & $\begin{array}{c}R s p=0.084 \\
p=0.206\end{array}$ \\
\hline & Yes & 3.50 & 3.44 & 3.13 & 3.31 & $\begin{array}{c}F(2.460)=0.838 \\
p=0.439\end{array}$ & $\begin{array}{c}\text { Rsp }=-0.188 \\
p=0.197\end{array}$ \\
\hline \multirow[t]{2}{*}{$\begin{array}{l}\text { Somatic } \\
\text { sphere }\end{array}$} & No & 40.61 & 41.25 & 44.43 & 42.28 & $\begin{array}{c}F(2.227)=1.693 \\
p=0.186\end{array}$ & $\begin{array}{c}\text { Rsp }=0.123 \\
p=0.063\end{array}$ \\
\hline & Yes & 62.56 & 64.11 & 59.92 & 61.55 & $\begin{array}{c}F(2.460)=0.384 \\
p=0.683\end{array}$ & $\begin{array}{c}\text { Rsp }=-0.054 \\
p=0.711\end{array}$ \\
\hline \multirow{2}{*}{$\begin{array}{l}\text { Psycho- } \\
\text { logical } \\
\text { sphere }\end{array}$} & No & 40.70 & 44.96 & 45.52 & 43.57 & $\begin{array}{c}F(2.227)=1.438 \\
p=0.240\end{array}$ & $\begin{array}{c}\text { Rsp }=0.109 \\
p=0.098\end{array}$ \\
\hline & Yes & 67.19 & 58.33 & 57.00 & 60.57 & $\begin{array}{c}F(2.460)=1.530 \\
p=0.227\end{array}$ & $\begin{array}{c}\text { Rsp }=-0.213 \\
p=0.141\end{array}$ \\
\hline \multirow[t]{2}{*}{$\begin{array}{c}\text { Social } \\
\text { sphere }\end{array}$} & No & 52.66 & 52.57 & 55.12 & 53.62 & $\begin{array}{c}F(2.227)=0.436 \\
p=0.647\end{array}$ & $\begin{array}{c}\text { Rsp }=0.052 \\
p=0.429\end{array}$ \\
\hline & Yes & 69.87 & 70.11 & 64.33 & 67.20 & $\begin{array}{c}F(2.46)=0.491 \\
p=0.615\end{array}$ & $\begin{array}{c}\text { Rsp }=-0.084 \\
p=0.566\end{array}$ \\
\hline \multirow{2}{*}{$\begin{array}{l}\text { Environ- } \\
\text { mental } \\
\text { sphere }\end{array}$} & No & 50.23 & 52.96 & 53.29 & 52.06 & $\begin{array}{c}F(2.227)=0.964 \\
p=0.383\end{array}$ & $\begin{array}{c}\text { Rsp }=0.061 \\
p=0.356\end{array}$ \\
\hline & Yes & 68.13 & 66.78 & 63.71 & 65.71 & $\begin{array}{c}F(2.46)=0.414 \\
p=0.663\end{array}$ & $\begin{array}{c}\text { Rsp }=- \\
0.113 p=0.441\end{array}$ \\
\hline
\end{tabular}

People like that have a higher quality of life right from the start. It was proved by the research done by Zawadzka et al. (11). Professional work affects the quality of life (11). The possibility of earning money is a strong motivational factor to come back to work for people after stroke, however, the importance of making money becomes smaller in comparison with other psychological benefits. It is emphasized by Cholewa et al. or Hartke \& Trierweiler $(13,14)$. Taking into consideration the professional activity of people after stroke in the presented material, Zawadzka's et als' opinions about the lower quality of life among not working people is confirmed (11). According to Kowalczyk et al. (15) not doing any professional work largely negatively affects the quality of life. In examination done by Tasiemski et al. was proved that possibility of starting a job after stroke is one of the most important factors affecting the quality of life (16).

Results of numerous foreign research investigations show that possibility of starting a job is one of the most important factors affecting quality of life after stroke $(17,18,19)$. Research done by Muli et al. (20) show higher quality of life of working people than people who do not work. 
Research done by Muss et al. in a group of 105 patients in Denmark with the use of the SSQoLDK scale shows a better quality of life of working people than people who do not work (21). Westerlind et al. showed that people who resumed professional work after stroke had a higher quality of life than people who did not (2). Koch et al., Medin et al. noticed that resuming work may have a positive effect on good mental mood of people after stroke and satisfy many psychosocial needs $(22,23)$. Maruthappu et al. came to think that unemployment is a potential risk factor of death in the case of cerebrovascular diseases (24). In research done by Vestling et al., $41 \%$ resumed work, although changes of employers, working hours, and duties appeared. People who resumed work reported a much higher level of subjective good mood and satisfaction from work (17).

Research done by Tasiemski et al. shows that there were $24 \%$ of working people after stroke, however the whole group of examined people included only 25 persons (16). Examination done in a group of 279 people showed that there was $17.56 \%$ of people who resumed work after stroke. It is important to emphasize that if people who do blue-collar jobs do not get fully operational before stroke they are forced to make a living from a social benefit that they receive, which in turn results in their lower economic status and lower quality of life. Resuming work after stroke among people of working age should be a priority target of holistic rehabilitation because it provides the feeling of social identity and is connected to improving one's self-esteem and satisfaction from life. When resuming work one must think about existing barriers hindering employment of people after stroke. It may be physical barriers, cognitive barriers, and also psychosocial and environmental factors, which is shown by Wang et al. (25). Time which passed since stroke is a frequent factor of including in the examination. In self-examination, the analysis of patients referred to 6 months to 5 years with the following division: 6-12, 13-24 and 25-60 months since the first stroke with the aim of assessing future treatment results and their effect on the quality of life (26). The connection between time since stroke and quality of life of professionally active and not active people after stroke. Obtained results allow a conclusion that time that passed since stroke is not statistically important in assessing quality of life of examined people. Assessment of the level of the quality of life done by Kowalczyk et al. showed that there is need for multi-directional research with the aim of improving level of life quality in all its spheres, in the case of people after stroke considering their life situation, functional status and the sick person's expectations (7). This research is part of realizing the strategy and health policy of the country included in The National Health Program (20162020) whose aim is "prolonging life in health; improving health and the quality of life of people as well as reducing social health inequalities".

\section{Conclusions}

1. Starting professional work by people after stroke considerably affected higher self-esteem; quality of life; satisfaction from health independent of the time since stroke. It emphasizes the role of professional activity as a factor in improving the quality of life.

2. The people after stroke who start professional work value quality of life much higher than people who do not work. Quality of life in social and environmental aspects was valued highest. Favorable effect of professional activity on somatic and psychological aspects of life of working people in comparison to people who do not work.

3. As a result of life being considerably longer, the aim of health and social policy should be improving quality of life for people after stroke of working age by means of improving chances of resuming work after stroke. Changing profession will help to do that. Likewise, the need for an holistic approach in the rehabilitation of people after stroke is on the rise.

\section{References}

1. RACIBORSKI F, GUJSKI M (2016) Strokes - A Growing Problem in an Aging Population. Warsaw: Raport Instytutu Ochrony Zdrowia, 2016.

2. WESTERLIND E, PERSSON HC, SUNNERHAGEN KS (2017) Return to work after a stroke in working age persons; A sixyear follow up. PLoS One. 2017. doi: 10.1371/journal.pone.0169759

3. HARTKE RJ, TRIERWEILER R (2015) Sur- 
vey of survivors' perspective on return to work after stroke. Topics in stroke rehabilitation. 2015,22(5),326-334. doi: 10.1179/1074935714Z.0000000044.

4. TREGER I, SHAMES J, GIAQUINTO S, RING H (2007) Return to work in stroke patients. Disabil Rehabil. 2007,29(17),13971403. doi:10.1080/09638280701314923.

5. HOFFMAN J, ZBONIK M, HOFFMAN A, SOCHANEK M (2017) The role of rehabilitation in the treatment of stroke patients. In: Podgorska M.(eds). Diseases of the 21st century - challenges of a physiotherapist. Gdansk: Wydawnictwo Wyższej Szkoły Zarządzania w Gdansku, 2017.

6. KOWALCZYK B (2018) Rehabilitation and the quality of life of people after stroke. Krakow: Wydawnictwo AWF, 2018.

7. KOWALCZYK B, ZAWADZKA B (2019) The level of physical fitness and the quality of life after stroke in people of working age. Probl Hig Epidemiol 2019;100(1):42-49.

8. WOŁOWICKA L. [red.] (2001) The quality of life in medical science. Poznań: Wydawnictwo Uczelniane Akademii Medycznej im. Karola Marcinkowskiego w Poznaniu, 2001: 291-300.

9. PRUSIŃSKI A (2011) Neurology in Practice. Warszawa: PZWL, Poland, 2011.

10. MAZUREK J, BLASZKOWSKA A, RYMASZEWSKA J (2013) Rehabilitation after stroke - current guidelines. Nowiny Lekarskie 2013;82(1):83-88.

11. ZAWADZKA J, BEJER A, KWOLEK A (2014) The influence of chosen socio-demographic factors on life quality of the stroke patients - introductory research. Przegląd Medyczny Uniwersytetu Rzeszowskiego 2014;1:36-46.

12. WEBER-RAJEK M, CIECHANOWSKA K, MIESZKOWSKI J, NIESPODZIŃSKI B, WYCECH M, PERZYŃSKA A (2014) Impact of mental health resources on the quality of life of patients after stroke. Journal of Health Sciences 2014;4(9):51-60.

13. CHOLEWA J, GORZKOWSKA A, NAWROCKA A (2017) Quality of life of people with Parkinson's disease in the context of professional work and physiotherapy. Medycyna Pracy 2017;68(6):725-734. doi: 10.13075/mp.5893.00590.
14. HARTKE RJ, TRIERWEILER R (2015) Survey of survivors' perspective on return to work after stroke. Topics in stroke rehabilitation 2015;22(5):326-334. doi: 10.1179/ $1074935714 Z .0000000044$.

15. KOWALCZYK B, ZAWADZKA B, LUBIŃSKA-ŻĄDŁO B (2016) The quality of life and social exclusion of working-age people after stroke. In: Kalátová $\mathrm{D}$, Beňo $\mathrm{P}$, Šramka M.[red.]. Zdravotné problémy marginalizovaných skupin. Ošetřovatelství, kvalita života, onkologie, veřejné zdravotnictví, laboratorné vyšetřovací metody farmakologie. Pribram, 2016:96-109.

16. TASIEMSKI T, KNOPCZYŃSKA A, WILSKIM (2010) Quality of life after stroke - pilot study. Gerontologia Polska 2010;18(3):128-133.

17. VESTLING M, TUFVESSON B, IWARSSON S (2003) Indicators for return to work after stroke and the importance of work for subjective well-being and life satisfaction. $J$. Reh. Med. 2003;35:127-131.

18. VESTLING M, RAMEL E, IWARSSON S (2005) Quality of life after stroke: wellbeing, life satisfaction and subjective aspect of work. Scand J Occup Ther. 2005;12:8995. doi: 10.1080/11038120510031770

19. DUFF N, NTSIEA MV, MUDZI W (2014) Factors that influence return to work after stroke. Occupational Health Southern Africa 2014;20(3):6-12. Available at : https://journals.co.za/content/ohsa/20/3/EJC154385.

20. MULI G, RHODA A (2013) Quality of life amongst young adults with stroke living in Kenya. African Health Sciences 2013;13(3):632-638. doi:10.4314/ahs.v13i3.16.

21. MUSS I, PETZOLD M, RINGSBERG KC (2010) Health-related quality of life among Danish patients 3 and 12 months after TIA or mild stroke. Scand J Caring Sci. 2010;24(2):211-218. doi: 10.1111/j.14716712.2009.00705.x.

22. $\mathrm{KOCH}$ L, EGBERT $\mathrm{N}$, COELING $\mathrm{H}$, AYERS D (2005) Returning to work after the onset of illness: experiences of right hemisphere stroke survivors. Rehabil Couns 2005;48:209-218. doi: $10.1177 / 00343552050480040201$.

23. MEDIN J, BARAJAS J, EKBERG K (2006) 
Stroke patients' experiences of return to work. Disabil Rehabil 2006;28:1051-1060. doi: 10.1080/09638280500494819.

24. MARUTHAPPU M, SHALHOUB J, TARIQ Z, WILLIAMS C, ATUN R, DAVIES AH, (2015) Unemployment, government healthcare spending, and cerebrovascular mortality, worldwide 1981-2009: an ecological study. Int J Stroke. 2015;10(3):364-371. doi: 10. 1111/ijs.12408.

25. WANG YC, KAPELLUSCH J, GARG A (2014) Important factors influencing the return to work after stroke. Work. 2014; 47(4):553-539. doi:10.3233/WOR-131627.

26. OPARA J (2012) Clinimetry in neurology evaluation of the results of neurological rehabilitation. Warszawa: PZWL, Poland, 2012 . 